FIU Law Review

Fall 2008

\title{
Building Critical Race Methodologies in Educational Research: A Research Note on Critical Race Testimonio
}

Lindsay Perez Huber

University of California

Follow this and additional works at: https://ecollections.law.fiu.edu/lawreview

Part of the Other Law Commons

Online ISSN: 2643-7759

Recommended Citation

Lindsay P. Huber, Building Critical Race Methodologies in Educational Research: A Research Note on Critical Race Testimonio, 4 FIU L. Rev. 159 (2008).

DOI: https://dx.doi.org/10.25148/lawrev.4.1.15

This Symposium is brought to you for free and open access by eCollections. It has been accepted for inclusion in FIU Law Review by an authorized editor of eCollections. For more information, please contact lisdavis@fiu.edu. 


\title{
Building Critical Race Methodologies in Educational Research: A Research Note on Critical Race Testimonio
}

\author{
Lindsay Perez Huber
}

\section{INTRODUCTION}

It has been over a decade since Critical Race Theory (CRT) has been utilized as a theoretical framework to analyze the role of race, racism, and other forms of oppression in the lives of People of Color ${ }^{2}$ within the field of education. It is an invaluable tool for critical scholars who seek to expose and disrupt oppressive conditions within education institutions in the U.S. However, after years of CRT scholarship in the field of education, a question that continues to be posed is - how do we do Critical Race Theory? Several CRT scholars in education have responded to this question through conceptualizations of critical race pedagogy and curriculum as tools to be utilized in teaching (Solorzano \& Yosso, 2001; Yosso, 2002). As Solorzano and Yosso (2002) argue, what is still needed in critical race scholarship in education is a variety of critical race methodologies ${ }^{3}$ that CRT scholars can use in research.

As a presenter at the twelfth annual LatCrit conference in Miami, Florida, I participated in a panel with several co-authors to present a developing conceptual framework we call racist nativism (Perez Huber et al., 2008). During this panel, we described how we utilized a LatCrit theoretical framework to show the inextricable link between race and immigration in the current historical moment. We further developed the concept of racist nativism as a research tool to better understand the experiences of undocumented communities. Since this presentation, my co-authors and I have engaged in many discussions about LatCrit and racist nativism and their

\footnotetext{
1 Lindsay Perez Huber is a doctoral candidate at the University of California, Los Angeles (UCLA) Graduate School of Education and Information Studies in the division of Social Science and Comparative Education.

2 People of Color is intentionally capitalized, rejecting the standard grammatical norm, to represent a grammatical move towards social/racial justice and empowerment. The same rule will apply for Communities of Color, Students of Color, and Scholars of Color.

3 According to Solorzano and Yosso (2002), critical race methodology in educational research provides researchers with strategies to understand the experiences of Students of Color by centering their experiences and responses to the U.S. education system within a historical and contemporary context. This term will be further discussed in the section on "critical race methodologies".
} 
function beyond that of a conceptual and theoretical frame, to become imbedded in the way we design our methodologies, including our methods, data collection, and data analysis during the research process. Many times, we arrive at more questions than answers. One question we continue to ask ourselves and each other is-how do critical race researchers in education design a CRT research study?

As critical race theorists, we know CRT can be used to illuminate the oppressive realities that mediate the experiences of People of Color. Critical race scholarship in education continues to evolve from the challenges and critiques it receives because of its approach to unapologetically center oppressive structures such as racism, sexism, and classism in research analysis. Perhaps in part due to this constant critique, CRT has become a strong and carefully developed theoretical framework. However, the need to further develop the use of CRT in the research process itself is a necessity, regardless of our respective fields (Education, Law, Ethnic Studies, Women Studies, etc.), or our CRT specializations (LatCrit, AsianCrit, FemCrit, WhiteCrit, etc.). The objective of this article is to begin an interdisciplinary dialogue within the CRT community about how we can further develop critical race methodologies. Being more explicit in the how we use CRT in the methodological approaches we use, we can provide each other (and future critical race researchers) with an invaluable set of "tools" to conduct critical race research in multiple academic fields. We should locate this dialogue within a larger discussion of how we can imbed CRT into all elements of the research process, including the ways we formulate our research questions, epistemological standpoints and methodological approaches (Solorzano \& Yosso, 2002). To begin this dialogue, this article will first briefly discuss the need to deconstruct Eurocentric research paradigms that can perpetuate dominant ideologies rooted in white superiority. Second, several research methodologies currently used by CRT scholars in the field of education are presented. Third, I describe how I have borrowed from the work of testimonio to develop the methodology of critical race testimonios.

\section{DeCOnSTRUCting THE APARTHEID OF KNOWLEDGE: THE NEED FOR A CRITICAL RACE THEORY PARADIGM}

Higher education in the United States is founded on a Eurocentric epistemological perspective based on white privilege and "American democratic" ideals of meritocracy, objectivity, and individuality. This epistemological perspective presumes that there is only one way of knowing and understanding the world, and it is the natural way of interpreting truth, knowledge, and reality. 
Delgado Bernal \& Villalpando (2002, p. 171).

In the epigraph above, Delgado Bernal and Villalpando (2002) argue the academy has historically functioned from a Eurocentric epistemological perspective that perpetuates dominant ideologies rooted in white superiority, creating what they call an apartheid of knowledge in American higher education. The academy is recognized as a central site of knowledge production, where researchers determine what constitutes valid and legitimate sources of knowledge. Similarly, Córdova (1998) explains the role the academy has played in "establishing knowledge as a discourse of power, where power to decide what is considered truth or not, is tied to the power to legitimate that truth" (p.17). The legitimation of knowledge as a function to protect elite interests has been well documented. Apartheid of knowledge (Delgado Bernal \& Villalpando, 2002), academic colonization (Córdova, 1998), regime of truth (Foucault, 1977), and epistemological racism (Scheurich \& Young, 1997) are some of the ways the process of legitimating and de-legitimating knowledge has been named. Countless Scholars of Color have expressed the need to deconstruct dominant perspectives rooted in white superiority (Anzaldúa, 1999; Córdova, 1998; Delgado Bernal \& Villalpando; Hurtado, 2003; Dillard, 2000; González, 1998; LadsonBillings, 2003; Smith, 1999). In the process of deconstructing this apartheid of knowledge, we can facilitate a more humanizing and liberating research process.

Ladson-Billings (2003) traces back the opposition to Eurocentric epistemologies over one hundred years ago, with the work of W.E.B. Dubois in The Souls of Black Folk. In this book, DuBois describes how AfricanAmericans living in a post-emancipation era in the U.S. struggle with double consciousness, the conflict between the desire to become a part of mainstream white society and to reject it from a solely African-American perspective. Years later, Memmi (1974) further articulates this struggle as a psychological warfare that takes place within the consciousness of the colonized. Anzaldúa (1999) injects issues of ethnicity, gender, class, and sexuality into these conversations, theorizing the contemporary experiences of Chicanas (la mestiza) who are constantly "straddling" the often conflicting perspectives of white, Mexicana/o, and indigenous cultures to make sense of our realities. The work of scholars such as DuBois, Memmi, and Anzaldúa articulate the struggles that arise as we attempt to define and understand our experiences as People of Color, within the constructs of dominant Eurocentric, partriarchical paradigms.

Richard Delgado (1984) shows how research becomes defined by dominant paradigms through the exclusion of alternative perspectives in civil rights law, and specifically, the exclusion of Scholars of Color. Delgado 
found that among the leading civil rights law reviews, the vast majority of articles were authored by white male scholars. Furthermore, he found most works cited within these law reviews to also be authored by white male scholars. Delgado names this process imperial scholarship, where a single perspective can define an entire field. In the case of civil rights law, and arguably in many other academic fields, this is an elite white male perspective. Delgado argues imperial scholarship in the academy can be dangerous, as it creates limited discourse, ideologies, and perspectives that justify and maintain white superiority.

Denzin and Lincoln (2003) allude to imperial scholarship as it has translated into a narrowly constructed research process, specifically in the area of qualitative research. Much of the CRT research in education utilizes qualitative methods to document the complex ways systems of oppression can impact the experiences of People of Color. As a highly utilized research strategy in CRT scholarship, it is important to recognize how qualitative research can limit our perspectives as researchers (Parker \& Lynn, 2002). Vidich \& Lyman (2003) explain how qualitative research emerged from the desire to understand the "other." Bell hooks (1990) argues that this desire was borne from the racist ideologies of white male researchers who sought to document the "primitive" ways of the dark-skinned "other." Acknowledging the problematic origins of qualitative research, scholars have alluded to the need to develop new theories, epistemologies, and methodologies in qualitative research that can help researchers more critically document, discuss, and analyze phenomenon related to race, class, and gender (Anzaldúa, 1990; Delgado Bernal, 2002; Denzin \& Lincoln, 2003; Smith, 1999). Bell hooks (1990) would argue this shift in qualitative research must consciously encompass an anti-racist agenda. This shift should also encompass an anti-hierarchical relationship that deconstructs the power dynamics of the researcher-subject relationship present in traditional paradigms.

Critical race scholarship acknowledges the century-long struggle Scholars of Color have endured to understand the experiences of People of Color from a Eurocentric perspective. A CRT framework functions to deconstruct the "apartheid of knowledge" that exists within the academy, through validating and honoring our own experiences and forms of knowledge. What is needed in CRT scholarship in education are clearly articulated strategies to use CRT in the research process. As critical race scholars, we engage in these strategies each time we take on a research project. We use CRT as a framework to guide us through the process of producing studies that seek to centralize the experiences of People of Color whose lives are mediated by oppressive conditions and to challenge dominant ideologies that perpetuate those conditions. To clearly articulate how CRT is 
used in our epistemological and methodolological approaches, we work towards dismantling the Eurocentricity of traditional research paradigms by centering the experiences of People of Color.

\section{RACE AND RACISM IN EDUCATION}

Aside from and prior to explaining how CRT is utilized in the research process, we must be clear in how we define race and racism, as these concepts are central to a CRT analysis. We should also be clear about how we use the theoretical tenants of CRT in our respective studies to achieve our research objectives. In line with these suggestions, I describe how I have come to understand race and racism, CRT, and specifically, Latina/o Critical Race Theory (LatCrit) in education.

\section{A. Defining Race.}

Race is a topic that should not be subsumed under culture or diversity but needs to be confronted directly because, today and throughout the course of U.S. history, it is and has been a critical factor associated with who does and does not benefit from available social, economic, and educational commodities.

Carter and Goodwin (1994, p. 293)

While many definitions of race exist, most scholars agree that race is a socially constructed category (Omi \& Winant, 1994; Haney-López, 2000; Solorzano \& Yosso, 2002). Racial definitions are fluid and have changed throughout history to allocate and deny power (through racism) to specific groups of people according to their place in a racial hierarchy. Despite the term's fluidity, the power of race and racism in mediating the lives of People of Color should not be underestimated (Haney-López, 2000). As Carter and Goodwin (1994) argue in the epigraph above, because of the power of race to mediate the lives of People of Color, it should be confronted directly. In order to challenge racism, we must first be clear in how we define race.

Banks (1995) defines race as, "a human invention constructed by groups to differentiate themselves from other groups, to create ideas about the 'Other,' to formulate their identities and to defend the disproportionate distribution of rewards and opportunities within society" (p. 22). Banks describes race as a socially constructed category used to maintain and perpetuate racism through racial hierarchies that create social inequities (via institutional racism). Banks acknowledges how power is mediated through the construction of racial definitions to benefit whites, which validates white values, beliefs, and knowledge over that of others. The validation and normalization of this hegemonic knowledge constructs particular per- 
ceptions of People of Color and provides specific privileges to whites. These privileges normalize white values, beliefs, and experiences as dominant and legitimate in U.S. society, while simultaneously invalidating and subordinating People of Color (Delgado \& Stefancic, 2001; Gillborn, 2006; Sue, 2003).

\section{B. Defining Racism}

The definition of race as a means of subordinating People of Color leads to the understanding of racism as an ideological function of white supremacy. White supremacy can be understood as a system of racial domination and exploitation where power and resources are unequally distributed to privilege whites and oppress People of Color (Bonilla-Silva, 2003; Dubois, 1999; Roediger, 1999). Solorzano, Allen, and Carroll (2002), provide three fundamental premises of racism that include: "(1) one group believes itself to be superior, (2) the group that believes itself to be superior has power to carry out the racist behavior, and (3) racism affects multiple racial/ethnic groups." Thus, Solorzano, Allen, and Carroll frame racism as institutional power that People of Color have never significantly possessed and has been protected by racist ideologies rooted in white supremacy.

Memmi (1968) adds an important component to the understanding of racism, highlighting the significance of perceptions of racial differences. Memmi defines racism as, "the generalized and final assigning of values to real or imagined differences, to the accuser's benefit and at [her or] his victim's expense, in order to justify the former's own privileges and aggression" (p.185). Thus, one can be victimized by racism, despite the reality of whether or not any real differences exist. This explanation of racism helps us understand how race, a socially constructed category, can manifest itself through an ideology of white supremacy, based on racialized perceptions of difference. These differences are what Bell (2004) describes as the "invisible" force that ensures People of Color maintain a perpetual subordinate position in U.S. society.

Notions of meritocracy and racial colorblindness protects, what Lipsitz (1998) describes as a "possessive investment in whiteness". This investment protects white privilege, perpetuates racism and ensures racial inequality (Marable, 2002; Bonilla-Silva, 2003; Bell, 2004). Critical scholarship, as such named here, has established that race and racism impact the lives of People of Color. Understanding race as a vehicle to allocate and deny power, knowledge, and rights to particular groups of people through racism, demonstrates the significance in examining how race and racism can mediate the daily experiences of People of Color. Moreover, this understanding demonstrates the significance of utilizing a theoretical framework that 
allows researchers to expose and understand how race, racism, and other forms of oppression are strategically used to subordinate People of Color. As much as the previous scholarship on race suggest, research must operate to expose racism and disrupt racist structures, practices and discourses that maintain and perpetuate racial inequality. CRT aims to achieve these goals.

\section{CRITICAL RACE THEORY \& LATINA/O CRITICAL RACE THEORY IN EDUCATION}

\section{A. Critical Race Theory in Education}

Educational researchers utilize a CRT framework in education to highlight the prominent role of race and racism in education systems and institutions that impact the educational trajectories of People of Color. A critical race analysis allows for and enables researchers to work towards the elimination of racism through understanding the multiple ways People of Color experience subordination, as defined by race, class, gender and other forms of oppression.

Solorzano and Yosso (2001) describe five central tenants of a CRT framework in education, which include:

(1) the centrality and intersectionality of race and racism with other forms of subordination;

(2) the challenge to dominant ideologies;

(3) the commitment to social justice;

(4) the importance of experiential knowledge; and

(5) the use of interdisciplinary perspectives.

Through these tenants, the researchers describe how multiple forms of subordination, such as class and gender, intersect with race and racism and must be examined to understand the experiences of People of Color. CRT challenges dominant, Eurocentric beliefs in notions of objectivity, meritocracy, and race neutrality that function to justify social inequities. In my own research, I focus on the experiences of Latina/o students. Thus, I have found a LatCrit theoretical framework to be especially useful.

Solorzano and Delgado Bernal (2001) highlight other forms of oppression that mediate the experiences of Latinas/os specifically, such as immigration status, language, ethnicity, culture and phenotype. These specific forms of oppression are considered in a Latina/o Critical Race Theory framework, or, LatCrit. LatCrit can be defined as an "anitsubordination and anti-essentialist project that attempts to link theory with practice, scholarship with teaching, and the academy with the community" (Solorzano \& Delgado Bernal, 2001, p. 312). A LatCrit framework follows the same five 
elements of CRT and includes the same overall goals. It is important to understand LatCrit and CRT as compatible, non-opposing, theoretical frameworks (Solorzano and Delgado Bernal, 2001). LatCrit is different from CRT in that it is concerned with a notion of coalitional Latina/o panethnicity, engendering a sense of empowerment among the Latina/o community. Moreover, LatCrit enables researchers to better articulate the experiences of Latinas/os, through a more focused examination of the multiple forms of oppression committed against Latina/o communities.

\section{CRITICAL RACE METHOdOLOGIES}

CRT research in education has utilized various research methodologies and methods. ${ }^{4}$ However, few of them have been explicitly linked to CRT. For example, many studies have utilized CRT to analyze educational attainment data and highlight racial disparities that exist for Students of Color (Solorzano \& Ornelas, 2004; Solorzano, Villalpando \& Oseguera, 2005; Watford et al., 2006; Yosso, 2006). Mostly, CRT has been used as theoretical perspective to help researchers identify racial inequities and to better understand the social contexts which create those inequities. Solorzano and Yosso (2002) highlight the need to develop critical race methodologies which draw from the forms of knowledge which exist in Communities of Color. These methodologies explicitly utilize a CRT lens which reveals experiences with and responses to racism, classism, sexism and other forms of oppression in education. Critical race methodologies challenge the Eurocentricity of traditional research paradigms and offer a liberatory and transformational meaning to academic research. Critical race methodologies provide researchers with the tools needed to conduct critical race research, guided by an explicit anti-racist, anti-hierarchical, racial, and social justice agenda. The following section will focus on existing critical race methodologies in educational research.

\section{A. Critical Race Counterstories}

Counterstorytelling may be the most widely-used CRT method, first used by critical race legal scholars such as Derrick Bell in Faces at the Bottom of the Well: The Permanence of Racism (1992) and Richard Delgado's Rodrigo's Chronicles (1995). In 2000, Daniel Solorzano and Tara Yosso brought counterstorytelling to the field of education in their book chapter,

4 In this article, it is important to note the difference between a research methodology and method. A methodology or methodological approach traditionally includes sampling procedures, data collection strategies, and data analysis. A research method is the data collection strategy used in the study, for example, interviews or focus groups. 
Toward a Critical Race Theory of Chicana and Chicano Education. Several years later, Yosso (2006) published the first book of critical race counterstories in education titled, Critical Race Counterstories Along the Chicana and Chicano Educational Pipeline. Delgado Bernal and Solorzano (2001) provide several basic tenants for critical race counterstories in education. They explain that counterstories can be used to:

(1) build community among those at the margins of society by putting a human and familiar face to educational theory and practice;

(2) challenge the perceived wisdom of those at society's center;

(3) open new windows into the reality of those at the margins of society by showing the possibilities beyond the ones they live and to show that they are not alone in their position; and

(4) teach others that by combining elements from both the story and the current reality, one can construct another world that is richer than either the story or the reality alone.

Critical race counterstories can be used as powerful tools to challenge majoritarian stories rooted in a dominant Eurocentric perspective that justify social inequities and normalize white superiority (and thus, white supremacy). Delgado and Stefancic (1993) define majoritarian stories as a "bundle of presuppositions, perceived wisdoms, and shared cultural understandings persons in the dominant race bring to the discussion of race" (p. 462). Critical race counterstories are a direct challenge to majoritarian stories because of the way they disrupt dominant perceptions of race to reveal the realities of racism, classism, sexism, and other forms of subordination experienced by People of Color. However, counterstories are not created solely as a response to majoritarian stories (Solorzano and Yosso, 2002). Through telling critical race counterstories, we humanize the struggles and injustices faced by People of Color within academic research, calling attention to racist structures, policies, and practices in education.

\section{CRitical Race Spatial Analysis}

An emerging CRT methodology in education being developed by Daniel Solorzano and Veronica Velez (2007) is Critical Race Spatial Analysis (CRSA). Using Geographic Information Systems ${ }^{5}$ (GIS) mapping technol-

5 Geographic Information Systems (GIS) is a collection of computer software, hardware, and geographic data that can be used to document, analyze, and manage geographic information. The GIS program can link information, or attributes (i.e., census tracks) to specific geographic locations. Further information can then be layered to create interactive maps, databases and models of information that can 
ogy, these researchers have created a visual representation of how race and racism physically manifest within geographic locations. They define CRSA as, "an explanatory framework and methodological approach that accounts for the role of race and racism in examining geographic and social spaces and that works toward identifying and challenging racism within these spaces as part of a larger goal of identifying and challenging all forms of subordination" (Solorzano \& Velez, 2007). In examining the role of race and racism within such spaces, CRSA allows researchers to spatially examine how specific structural and institutional factors can influence and shape racial power dynamics within communities. CRSA in education can be used to examine how structural and institutional factors divide, constrict, and construct space that affects the educational opportunities of Students of Color.

Utilizing a CRSA method in educational research provides an important technologically advanced component for critical race methodologies, motivated by the tenants and goals of CRT. Moreover, CRSA provides an alternative representation of how race and racism can manifest within geographic locations to expose and acknowledge the multiple realities of multiple communities. Critical race scholars now have a powerful tool to visually represent the impact of race and racism within Communities of Color, making CRT scholarship accessible to a far wider audience.

Counterstorytelling and CRSA are powerful critical race methodologies that can be used to shift traditional research paradigms and center the multiple experiences and knowledges of People of Color in educational research. As critical race scholars, it is important to further develop methodologies which complement the efforts of CRT, to expose the realities of People of Color whose lives are mediated by various forms of oppression. One strategy in moving toward this goal can be to borrow from existing methods that are guided by similar tenants of CRT and make them our own. One such method that is especially compatible with the tenants of CRT, and in particular, LatCrit is testimonio.

\section{CRITICAL RACE TESTIMONIOS}

Testimonio emerged from Latin America as a tool to document the experiences of oppressed people, often within the context of war (Yúdice, 1991). Perhaps one of the most cited testimonios is I, Rigoberta Menchú: An Indian Woman in Guatemala (1984). In this work, Menchú delivers her testimonio to Venezuelan anthropologist Elisabeth Burgos-Debray, describ-

be used to answer specific questions related to geographic locations. See also Guide to Geographic Information Systems, What is GIS?, http://www.gis.com/index.html. (last visited May 19, 2007). 
ing the violence and death she survived as an indigenous Guatemalan women and active leader in the struggle for indigenous rights in her country. As was the case in I, Rigoberta Menchu, the researcher, or transcriber, usually documents the story of the narrator who describes her/his life events. The researcher poses questions to the narrator to prompt for the description of specific experiences or for purposes of clarification. However, it is the narrator's role to dictate what information will be shared during the testimonio and to present that information within a context she/he feels appropriate (Brabeck, 2004).

There is no single definition of testimonio or requirements for how this technique should be used in the research process, nor do I suggest there should be. Reviewing the ways testimonio has been described among various scholars, there were clear areas of overlap between the tenants of LatCrit and the elements that compose testimonio as a research method. I will briefly present how some scholars describe their understandings of testimonio as a research tool and explain how I see LatCrit to inform this technique. Finally, I use a LatCrit lens to frame how testimonio can be used in critical race research, through critical race testimonio.

Brabeck (2001) describes testimonio as a "verbal journey . . . of one's life experiences with attention to injustices one has suffered and the effect these injustices have had on one's life" (p. 3). The focus on narrative ${ }^{6}$ in testimonio allows researchers to document the stories of their participants while validating their experiential knowledge, a central tenet of LatCrit. The experiences the participant shares are focused on the injustices that they have experienced as a result of some form of oppression. Using a LatCrit theory frame, this oppression can be mediated by race, class, gender, immigration status or language (among others). Testimonio allows the participant to identify the forms of oppression that have affected their experiences, rather than the researcher defining those experiences for them.

Yúdice (1991) outlines several other significant elements of testimonio, which also compliment a LatCrit framework. He explains how the "witness" or "participant", becomes an agent of "collective memory and identity," providing their testimonio to reveal exploitative and oppressive conditions. Bartow (2005) emphasizes the use of testimonio as a "tool for human rights." These descriptions of testimonio are significant because they highlight the human agency in naming one's pain caused by the oppression they have experienced. Moreover, these descriptions suggest tes-

6 This article focuses on the narrative use of testimonio. However, testimonio can take various forms such as written, visual, and digital testimonios. For more information, see the work of Benmayor (2008) and Delgado Bernal (2008) who have developed the use of digital testimonios as classroom pedagogy in higher education. 
timonio to be a liberatory act, where the individual can be empowered by having their stories voiced. Recognizing differences and building coalitions among oppressed groups to become empowered is yet another overlap with a LatCrit framework.

Utilizing testimonio as a method in educational research is a challenge to traditional Eurocentric epistemology imbedded within and perpetuated by notions of white superiority (Delgado Bernal \& Villalpando, 2002). Again, referencing the work of Delgado Bernal \& Villalpando (2002), testimonio as a research method can be seen as a direct challenge to dominant epistemology, as what should constitute valid research and research processes. For example, a Eurocentric epistemology is rooted in dominant beliefs in objectivity, meritocracy, and individuality, which function to marginalize and oppress those who do not or cannot achieve such ideals. Testimonio, on the other hand, transcends these beliefs in several ways. First, the role of the researcher is not bound by objectivity. In fact, Brabeck (2004) suggests that the participant and researcher collaborate on the method of testimonio as an act of solidarity, while respecting each other's differences. Second, testimonio acknowledges the broader social contexts of oppression, such as war, poverty, and violence that impact and shape life experiences. Third, our individual experiences as People of Color whose lives are mediated by oppressive realities, speak beyond ourselves and to other groups who, collectively, can be empowered by letting our stories be heard. Testimonio is a methodological move toward the representation of a collective experience and community memory that can empower People of Color whose experiences are marked by oppression.

The method of testimonio can be seen as a direct challenge to dominant ideology because it functions to reveal oppression, rather than mask it. It is because of the power of testimonio to challenge dominant ideology, expose oppression and move towards social justice, that it can be used as a useful tool to conduct CRT research. Borrowing from some key elements of testimonio and applying a LatCrit frame, a critical race testimonio can be understood as, a verbal journey of a witness who speaks to reveal the racist, nativist, classist, and sexist injustices they have suffered as a means of healing, empowerment, and advocacy for a more humane present and future.

Testimonio has been traditionally used as a tool by Latin American literature scholars to document the experiences of oppressed communities. Research utilizing testimonio as a method within social science research is limited. However, the work of Burciaga (2007) demonstrates how critical epistemological standpoints can be used to enact the process of testimonio in educational research. Specifically, Burciaga identified the work of Delgado Bernal (1998) on Chicana feminist epistemology and the Latina Fe- 
minist Group (2001) to demonstrate the ways testimonio can be methodologically enacted in the research process.

A Chicana feminist epistemological framework helps researchers shift the center of traditional research paradigms to acknowledge and honor the lived experiences of Chicana researchers and research participants (Delgado Bernal, 1998). According to Burciaga (2007), positioning this study within a Chicana feminist epistemology "brings the method of testimonio to life" in educational research. Utilizing a Chicana feminist epistemology in this study allows the method of testimonio and in particular, critical race testimonio to be employed through what Delgado Bernal terms, cultural intuition.

According to Delgado Bernal (1998), there are four sources of cultural intuition Chicana researchers draw upon during the research process. The first source is the personal experience of the researcher. The researcher's background and personal history have shaped the ways that she understands, interprets, and makes sense of events, circumstances, and data during the research process. Similar to testimonio, this source of intuition is inclusive of "collective experience and community memory." The second source of intuition draws from how we make sense of related literature on our research topic. The third source originates from our professional experiences, often within our communities, that provide us with significant insight into the research process. The final source of cultural intuition lies in the analytical research process itself to "bring meaning" to our data and larger study. Furthermore, Delgado Bernal (1998) argues that a central tenet of a Chicana feminist epistemology is the inclusion of research participants into data analysis. This validates the assertion of the participants as equals in the study and allows the participants to ensure their experiences are being portrayed as they see accurate.

Cultural intuition validates the unique experiences and perspectives of Chicana researchers and enables us to utilize these experiences in conducting research. Moreover, utilizing cultural intuition allows the participants to engage in data analysis. Thus, cultural intuition validates the knowledge and experiences of Chicana researchers and participants. Through engaging in this collaborative process, the researcher and participants are able to document, analyze, and interpret experiences as the participants see accurate. Cultural intuition is especially compatible with the method of testimonio because of its goals to interrogate normalized epistemological frameworks and validate foundations of knowledge that are often marginalized in traditional academic research.

The Latina Feminist Group (2001), in their collaborative book, Telling to Live, elaborate on the method of testimonio as a theorizing process where researchers and participants create their own knowledge and theories to 
explain their life histories and experiences, what they call feminist latinidades. For these Latina scholars, testimonio was used as a method to create a reflective process of theorizing about their own experiences as Latina academics, engendered by "deseo, respeto, confianza, y colaboracion-a meshing of desire, respect, trust and collaboration" (p. 9). In the book, the authors stress that the process of testimonio was just as important as the final product of their work. Thus, the authors allude to the importance of testimonio functioning beyond a research method, to a methodological process which allows new ways of theorizing and knowledge production to emerge. In this way, the process and product of testimonio became a form of empowerment (Latina Feminist Group, 2001).

Borrowing from the work of the aforementioned scholars in education and literature, four central tenets of a critical race testimonio emerge. Critical race testimonios can:

(1) validate and honor the knowledge and lived experiences of oppressed groups by becoming apart of the research process;

(2) challenge dominant research paradigms that guide traditional forms of academic research, including epistemological and methodological perspectives;

(3) function within a collective memory that transcends a single experience to that of multiple communities; and

(4) be motivated by social and racial justice by offering a space within the academy for the urgent stories of People of Color to be heard.

Collectively, these tenets compliment a CRT theoretical framework. Critical race testimonios seek to document, analyze, and validate the experiences of People of Color as well as the researcher while working towards dismantling the apartheid of knowledge that perpetuates white supremacy and the forms of oppression it manifests within and beyond the academy. Moreover, in line with the findings of the Latina Feminist Group (2001), critical race testimonios will function to empower People of Color, both participant and researcher. Understanding testimonio as a research process, positioned within a Chicana feminist epistemological standpoint, explicitly focused on the experiences of People of Color, and guided by a social and racial justice agenda enable critical race testimonio to be employed as critical race methodology in educational research.

\section{CONCLUSION}

This article has discussed the need for CRT scholars to think about ways we can imbed CRT into the research process to further develop critical race methodologies in educational research. This move can contribute 
to challenge dominant Eurocentric research paradigms and deconstruct the "apartheid of knowledge" that has been created in the academy as a result. In doing so, we validate our experiences and forms of knowledge that have been shaped by our families, communities, and cultures. Moving towards this goal, I explained how I saw testimonio, to be especially compatible with a CRT framework and in particular, a LatCrit frame. I proposed the methodology of critical race testimonio that can be used in critical race research to more accurately portray the experiences of the Latina/o community. In the process of sharing our research strategies and engaging in dialogue around these issues, we can build a body of literature that more explicitly describes how we do CRT research, or, how CRT can guide the research process itself - from the research questions we ask, the epistemological and methodological standpoints we take, to how we analyze our data. As members of a CRT community, joined by our shared objectives of seeking social and racial justice for Communities of Color, we can work to build, share, and create research strategies to achieve these objectives. As Audre Lorde (1983) once suggested, "the master's tools will never dismantle the master's house." Perhaps it is time then, we create our own. 